\title{
EVALUATION OF VEGETABLE WASTES FOR ENHANCED PRODUCTION OF AMYLASE BY ASPERGILLUS NIGER ISOLATED FROM MARINE WATER ADOPTING SOLID STATE FERMENTATION
}

\author{
Karthick Raja Namasivayam S. ${ }^{1}$, Nirmala . $D^{2}$ \\ ${ }^{1}$ Department of Biotechnology \\ Sathyabama University Chennai,India \\ E.mail: ${ }^{1}$ skrn.microbiol@gmail.com
}

\begin{abstract}
The present study undertaken to evaluate vegetables wastes as a substrate for amylase production by solid state fermentation by Aspergillus niger originally isolated from marine water. Among 123 different fungal isolates reported,35 isolates belong to Aspergillus niger showed strong amylase activity. The wastes supported growth and enzyme activity at all parameters tested.Maximum activity was recorded at $0 \%$ moisture content,70 C and $\mathrm{pH}$ 9 at all incubation time
\end{abstract}

Key words: Amylase, Aspergillus niger,enzyme activity

\section{INTRODUCTION}

Amylases are one of the most important industrial enzymes that have a wide variety of applications ranging from conversion of starch to sugar syrups, to the production of cyclodextrins for the pharmaceutical industry. These enzymes account for about $30 \%$ of the world's enzyme production. The a-amylase family can roughly be divided into two groups: the starch hydrolyzing enzymes and the starch modifying, or transglycosylating enzymes (1)

Solid-state fermentation has emerged as a potential technology for the production of microbial products such as feed, fuel, food, industrial chemicals and pharmaceutical roducts. Its application in bioprocesses such as bioleaching, biobeneficiation, bioremediation, biopulping, etc. has offered several advantages. Utilisation of agro-industrial residues as substrates in SSF processes provides an alternative avenue and value-addition to these otherwise under- or non-utilised residues Enzymes are among the most important products obtained for human needs through microbial sources. A large number of industrial processes in the areas of industrial, environmental and food biotechnology utilize enzymes at some stage or the other. Current developments in biotechnology are yielding new applications for enzymes. Solid state fermentation (SSF) holds tremendous potential for the production of enzymes. It can be of special interest in those processes where the crude fermented products may be used directly as enzyme sources (2)
In the present study vegetable wastes were evaluated for amylase production and effect of parameters by Aspergillus niger isolated from marine water

\section{MATERIALS AND METHODS}

\section{A. Sample collection}

The sea water was collected in different sites of Marina Beach Chennai (Asia's $2^{\text {nd }}$ largest beach) By using the sterile autoclaved 2 liter water bottle and brought to the Laboratory immediately. And the samples were kept in the refrigeration at $4^{\circ} \mathrm{C}$ till samples were processed.

\section{B. Isolation of fungi}

The SDA media was used for isolation. The media was prepared in sea water, sterilized by autoclaving and poured in to sterile Petri plate and allowed to solidify. $25 \mathrm{ml}$ of the collected sea water was aseptically transferred to $250 \mathrm{ml}$ of sterile distilled water blank and mixed thoroughly. $10 \mathrm{ml}$ of the sample was transferred to $90 \mathrm{ml}$ of distilled water, shook vigorously and diluted. $0.1 \mathrm{ml}$ of the aliquot was spread plated on SDA media prepared with sea water, incubated at $30^{\circ} \mathrm{C}$ for 3-4 days.

The fungal colonies appeared on respective dilution was countered and streaked on SDA media separately to get pure culture. A single monosporic colony was selected and streaked on SDA slant as monosporic culture for further studies. The slants were stored at $4^{\circ} \mathrm{C}$ in refrigeration. Glycerol storage was also maintained. 


\section{Identification}

The respective fugal pure cultures was identified based on their morphological and cultural characteristics, microscopic examination of fungal spores with lactophenol cotton blue as per the criteria suggested by Humber (3).

\section{Screening for amylase production}

Primary screening was carried out to evaluate amylase producing fungi using Starch Agar media. 100 $\mathrm{ml}$ of the Starch Agar media was prepared in $250 \mathrm{ml}$ of conical flask, sterilized by autoclave and poured into the sterile Petri plate, allowed for solidification. A fully grown mycelial plug $(4 \mathrm{~mm})$ was cut 4 days old fungal culture on SDA plate, transferred to Starch agar media and incubated at $32^{\circ} \mathrm{C}$ for $3-4$ days. The plates were flooded with iodine solution. After the incubation period a clear zone was observed around the fungal colonies indicating amylase production.

The amylase producing fungi were selected and used for further study.

\section{E. Inoculum preparation}

The spores were obtained from 10 days old SDA slant culture of the fungi by scraping of the slant surface with sterile distilled water containing few drops of tween-20. The slurry obtained was filtered through masculine cloth to remove the mycelial debris and it was used as a source of inoculum. The spore count was done by the Heamocytometer.

$100 \mathrm{ml}$ of inoculum media was sterilized and inoculated with $0.1 \mathrm{ml}$ of spore suspension. $\left(10^{8}\right.$ spores $/ \mathrm{ml}$ ) of respective amylase producing fungi are incubated at $32^{\circ} \mathrm{C}$ for 4 days in a shaker at $250 \mathrm{rpm}$. After the incubation period the media filtered through filter paper, centrifuged at 10,000 rpm for $10 \mathrm{~min}$; the collected supernant was used as source of enzyme.

\section{F. Amylase assay}

$1 \mathrm{ml}$ of the supernant were added in the sterile test tube and it is diluted with $1 \mathrm{ml}$ of distilled water in addition to this $1 \mathrm{ml}$ of starch, $1 \mathrm{ml}$ of $\mathrm{NaOH}$ was added and kept in water bath at $40^{\circ} \mathrm{C}$ for 10 mins after the incubation period $1 \mathrm{ml}$ of DNS (Di nitro salicylic acid) is added in the test tube and OD was measured using colorimeter at $540 \mathrm{~nm}$.

\section{G. Amylase Production Using Vegetable Wastes}

Peel, pulp or non used portion of (Tomato, Potato, beans, onion, carrot, brinjal, and cauliflower) were collected from university mess in sterile polythene bags and brought to the laboratory. The wastes were allowed to shade dry for few hours to remove moisture content.

$25 \mathrm{gms}$ of the mixed waste vegetable transferred to $100 \mathrm{ml}$ of conical flask, the moisture content for each flask was adjusted to $0,10,20,40,60 \%$ with distilled water. The flask was sterilized by autoclave and it is inoculated with $0.1 \mathrm{ml}$ of fungal spore from inoculums media all the flask were kept at $30^{\circ} \mathrm{C}$ for 4-days and each day the enzyme assay was preformed.

\section{H. Enzyme extraction}

After the incubation period $5 \mathrm{gms}$ of mixed waste vegetables from the respective flasks were transferred to beakers and flooded with distilled water and mixed thoroughly with sterile glass rod, shook vigorously, filtered the suspension with filter paper and collected filtrates were used as crude enzyme source for further studies.

\section{Effect of $\mathrm{pH}$}

$1 \mathrm{ml}$ of crude enzyme was incubated with phosphate buffer of different $\mathrm{pH}$ ranged from $5,6,7$, 8,9 and 10 respectively at $32^{\circ} \mathrm{C}$ for $10 \mathrm{~min}$. The enzyme assay was carried out as described earlier.

\section{J. Effect of Temperature}

$1 \mathrm{ml}$ of crude enzyme was incubated with different temperature ranged from $30^{\circ} \mathrm{C}, 40^{\circ} \mathrm{C}, 50^{\circ} \mathrm{C}$, $60^{\circ} \mathrm{C}, 70^{\circ} \mathrm{C}$ respectively for 10 minutes. The enzyme assay was carried out as described earlier.

\section{RESULTS AND DISCUSSION}

\section{A. Generic composition of fungi isolates}

A total of 155 isolates belong to five different species were isolated and their generic composition was presented in Table 1. The isolated fungi were Aspergillus niger, Penicillium expansum, Gliocladium sp, Aspergillus $\mathrm{sp}$ and Penicilium $\mathrm{sp}$. Penicillium $\mathrm{sp}$ and Penicillium expansum were dominant followed by Aspergillus niger (Table 1) Burteseva et al., (2003) explained on filamentus marine fungi as producers of O-glycosyl hydrolase: $\beta-1, \quad 3$-glucanase from Chaetomium indicum and suggested that 90 fungal strains (42 species) isolated from marine habits were studied for their ability to produce extra cellular enzyme. 
Cultural filtrates of these strains were shown to contain a series of glycosidases which varied with habitat. The level of activity depended on the species of fungi. Optimal condition for growth of Chaetomium indicum and for biosynthesis of $\beta$-1,3-glucanase were determined $\beta$-1,3-glucanase was isolated using ion exchange chromatography, ultra filtration and gel filtration. The presence of two enzyme forms were shown: both forms were exo $\beta-1$, 3-glucanase.

Table 1. Generic composition of fungi isolated from marine water.

\begin{tabular}{|c|l|c|}
\hline S.No & \multicolumn{1}{|c|}{ Fungi } & Composition \\
\hline 1 & Aspergillus niger & $50 \%$ \\
\hline 2 & Gliocladium $s p$ & $25 \%$ \\
\hline 3 & Aspergillus $s p$ & $15 \%$ \\
\hline 4 & Penicillium expansum & $6 \%$ \\
\hline 5 & Penicillium $s p$ & $4 \%$ \\
\hline
\end{tabular}

B. Screening of Amylase Producing Fungi In Solid Plate Assay

The different fungal species were tested for screening of amylase production on solid plate assay using starch agar media. Among the five species Aspergillus niger and Gliocladium sp showed strong amylase activity as shown in Table 2.

Table 2. Screening of amylase production

\begin{tabular}{|c|c|c|}
\hline S.No & Fungi & Productivity of Amylase \\
\hline 1 & Aspergillus niger & +++ \\
\hline 2 & Gliocladium $s p$ & ++ \\
\hline 3 & Aspergillus $s p$ & + \\
\hline 4 & $\begin{array}{c}\text { Penicillium } \\
\text { expansum }\end{array}$ & + \\
\hline 5 & Penicillium $s p$ & + \\
\hline
\end{tabular}

++- high activity, + + - moderate activity, + - less activity

\section{Amylase Production Son Vegetable Waste}

\section{Effect of moisture content}

Among the different moisture content, enzyme activity was found to be maximum at $0 \%$ level followed by $10 \%$ and enzyme production was high at 96 hours of incubation (Table 3). The enzyme activity at $24,48,72$ and 96 hours was 50, 54, 62 and 74 Units/ml. (Table 3) similarly $43,45,55,62 \mathrm{Units} / \mathrm{ml}$ at $10 \%, 41,44,47$, 61 units $/ \mathrm{ml}$ at 20\%, 36, 43, 46, 56 units $/ \mathrm{ml}$ at $40 \%, 30$, $41,44,56$ Units $/ \mathrm{ml}$ at $60 \%$ was observed at 24,48 , 72, 96 hours of incubation respectively. Anil.Patel (1) have reported on $\beta$-amylase from fungal culture grown on oil cakes and its properties, the solid state fermentation was carried out for the production of $\beta$-amylase using Aspergillus oryzae. The oils such as sesame oil cake, groundnut oil cake, palm kernel cake and olive oil cake were screened to be used as substrate for the enzyme production and also compared with wheat bran (WB).

Table 3. Effect of moisture content (\%) on amylase activity

\begin{tabular}{|c|c|c|c|c|c|c|}
\hline S.No & $\begin{array}{c}\text { Incubation } \\
\text { time } \\
\text { (Hours) }\end{array}$ & \multicolumn{6}{|c|}{ Enzyme activity (u/ml) } \\
\hline & 0 & 10 & 20 & 40 & 50 & \\
\hline 1 & 24 & 50.0 & 43 & 41 & 36 & 30 \\
\hline 2 & 48 & 54.0 & 45 & 44 & 43 & 41 \\
\hline 3 & 72 & 62.0 & 55 & 47 & 46 & 44 \\
\hline 4 & 96 & 74.0 & 62 & 61 & 56 & 56 \\
\hline
\end{tabular}

\section{Effect of $\mathrm{pH}$ and temperature on amylase activity}

Maximum enzyme activity was recorded at 9.0 followed by 10.0 (62.1 and 66.6 units $/ \mathrm{ml}$ respectively) $58.5,60.7$ and 61.2 units $/ \mathrm{ml}$ activity was observed in the range of 5,6 and 7 respectively (Table 4)

Table 4. Effect of $\mathrm{pH}$ on amylase activity

\begin{tabular}{|c|c|c|}
\hline S.No & pH & $\begin{array}{c}\text { Enzyme activity } \\
\text { (Units/ml) }\end{array}$ \\
\hline 1 & 5.0 & 117.7 \\
\hline 2 & 6.0 & 118.2 \\
\hline 3 & 7.0 & 118.5 \\
\hline 4 & 8.0 & 120.2 \\
\hline 5 & 9.0 & 121.6 \\
\hline
\end{tabular}

Among the different temperature tested Maximum enzyme activity was recorded at $70^{\circ} \mathrm{C}$ followed by $60^{\circ} \mathrm{C}$ (167 and 196 units $/ \mathrm{ml}$ ) and $59.2^{\circ} \mathrm{C}$ units $\left./ \mathrm{ml}\right)$ respectively (Table 5 ) 
Table 5. Effect of Temperature on enzyme activity

\begin{tabular}{|c|c|c|}
\hline S.No & Temperature (C) & $\begin{array}{c}\text { Enzyme activity } \\
\text { (Units/ml) }\end{array}$ \\
\hline 1 & 30 & 121 \\
\hline 2 & 40 & 127 \\
\hline 3 & 50 & 141 \\
\hline 4 & 60 & 167 \\
\hline 5 & 70 & 196 \\
\hline
\end{tabular}

Mohapatra et al. (4) showed that associated with marine sponge spirastrella $s p$., grown at $30^{\circ} \mathrm{C}$. the enzyme has an optimal pH of 5.0 and an optimum temperature of $60^{\circ} \mathrm{C}$. the half lives of the partially purified enzyme at 55 and $60^{\circ} \mathrm{C}$ were 120 and 50 minutes.Frolova et al. (5) introduced the activity of the isolated amylase from Aspergillus flavipes forms decreased in the presence of proteolytic enzyme. New, highly stable forms of amylase (with $\mathrm{pH}$ optimum of 5.5 and 7.5 and the maximum activity at $60-80^{\circ} \mathrm{C}$ ) were synthesized in the presence of Diisopropyl flourophosphate, an inhibitor of Protease. Poornima et al (6) proposed $\alpha$-amylase activity of s.aureofasciculus was studied and the maximum enzyme activity is found at $\mathrm{pH} 9$, temperature $45^{\circ} \mathrm{C}$, $0.05 \% \mathrm{Nacl}$ concentration, carbon compound mannose and nitrogen compound L-histidine.

\section{REFERENCES}

[1] Anil Patil.2004. Production of amylase by fungal strains from marine using oil cakes. Marine Biologia, 7; 126-131.

[2] Burtseva.Yu.V., Verigina.N.S., Sova.V.V., Pivkin.M.V., and Zvyagintseva. T.N. 2003. Filamentous Marine Fungi as Producers of 0-Glycosylhydrolases: $b-1$, 3-Glucanase from Chaetomium indicum, Marine Biotechnology 5; 349-359.

[3] Humber V.1997. Fungi- Identification. Academic press,London p 236

[4] Mohapatra.B. R., Banerjee.U.C., and Bapuji M. 1998.Characterization of a fungal amylase from Mucor sp. associated with the marine sponge Spirastrella sp. Journal of Biotechnology 60; 113-117

[5] Frolova G. M., Sil'chenko.A. S., Pivkin.M. V., and Mikhailov.V.V. 2004. Amylases of the Fungus Aspergillus flavipes Associated with Fucus evanescens. journal of Applied Biochemistry and Microbiology 38 (2); 134-139.

[6] Poornima.R., Maloy kumar saku., Siva Kumar.K., and Pushpavalli.V, 2008. Optimization of $\alpha$-amylase production by Actinomycete strain AE-19 isolated from shrimp pond. Accadamic Journal, Terand in Application Science Research 3(1); 45-52.

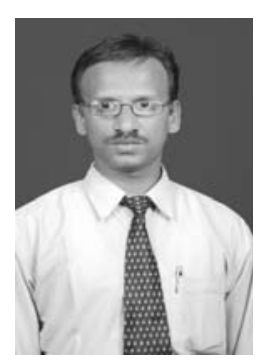

Dr. Karthick Raja Namasivayam is a Senior Lecturer in the Department of Biotechnology and has several National and International publications under his credit. His specialization is Microbiology and is actively involved in research. 